такая модель поведения либо мало характерна, либо не характерна вовсе, и они спокойно встречают проблемы и решают их.

$$
* * *
$$

1. Осницкий, А. К. Определение характеристик социальной адаптации / А.К. Осницкий // Психология и школа. - 2004. - №1.- C.43-56

2. Снегирёва Т.В. Методика изучения особенностей личностной саморегуляции // Диагностическая и коррекционная работа школьного психолога / Под ред. И. В. Дубровиной. - М., сборник трудов АПН CCCP, 1987.

3. Rogers, Carl R., and Rosalind F. Dymond, eds. Psychotherapy and Personality Change: Coordinated Research Studies in the Client-Centered Approach. Chicago: University of Chicago Press, 1954.

\title{
Нелюбина Е.Г. \\ Теоретико-методологические подходы к социально-психологической адаптации персонала на предприятии
}

Пензенский казачий институт управления и пищевых технологий (филиал) ФГБОУ ВО «Московский государственный университет технологий и управления имени К.Г. Разумовского (Первый казачий университет)»

(Россия, Пенза)

doi: 10.18411/trnio-10-2021-30

Научный руководитель Бочкарёва Л.П.

\section{Аннотация}

В статье рассмотрены теоретические и методологические подходы к рассмотрению вопросов по проблеме социально-психологической адаптации работников предприятий.

Ключевые слова: адаптация, социально-психологическая адаптация персонала, предприятие.

\section{Abstract}

The article discusses theoretical and methodological approaches to the consideration of issues related to the problem of social and psychological adaptation of employees of enterprises.

Keywords: adaptation, social and psychological adaptation of personnel, enterprise.

В настоящее время чрезвычайно актуальной является проблема адаптации личности. Удачное взаимное привыкание работника и организации благоприятно повлияет на их дальнейшее взаимодействие. Социально-психологическая адаптация сопровождает развитие организации, ее персонала и является необходимым для успешного приспособления и выживания организации в целом в изменяющихся условиях внешней среды [1,2]. Выделяют два типа социально-психологической адаптации, представленных на рисунке 1.

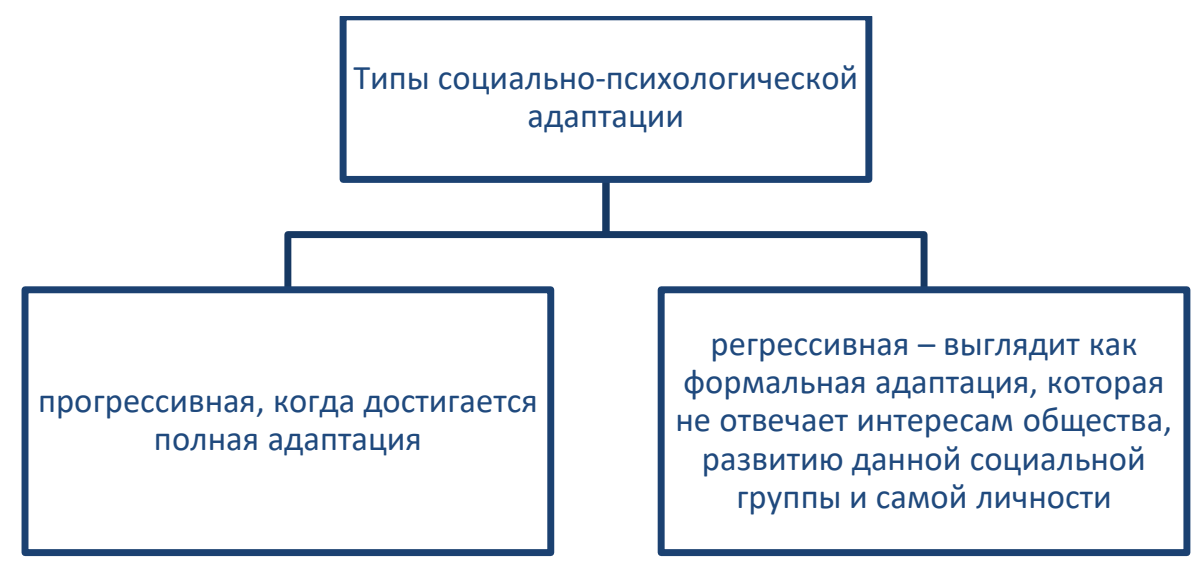

Рисунок 1. Классификаџия типов социильно-психологической адаптаџии 
Одними из составляющих успешного введения в новую должность нового сотрудника, или, другими словами, его адаптации, стоит выделить психологические аспекты. Социально-психологическая адаптация для многих представляется в виде специализированной подготовке человека к конкретной работе. Сотрудника обучают, посвящают во все производственные тонкости и внедряют в рабочий процесс. Однако все эти мероприятия направлены лишь на трудовую адаптацию сотрудника, призванную помочь ему выполнять его прямые организационные обязанности. Но ведь продуктивность его деятельности зависит не только от грамотного владения профессиональными навыками.

Социально-психологическая адаптация по утверждению А.И. Жмырикова - это сложный диалектический, многоуровневый и иерархически организованный процесс взаимодействия личности и социальной среды, приводящий к оптимальному соотношению целей и ценностей личности и среды, реализации внутриличностного потенциала в конкретных условиях жизнедеятельности при благоприятном эмоциональном самочувствии [3].

Социально-психологическая адаптация заключается в приспособлении молодого работника к правилам поведения, действующим в трудовом коллективе. Сюда входит ознакомление с целями и задачами коллектива, его традициями, отношениями между руководителями и подчиненными в условиях демократии и гласности, между смежными подразделениями, с критериями оценки действий работника в коллективных формах организации труда. Социально-психологическая адаптация - процесс вхождения новичка в новый для него производственный коллектив, формирования личностных связей и отношений с другими людьми.

Социально-психологическая адаптация выражается в формировании положительных неформальных отношений с коллегами по работе и руководителями, в достижении ценностного единства работника и коллектива. Основным объективным показателем социально-психологической адаптированности является отсутствие конфликтов с руководством и членами коллектива (рисунок 2) [4].

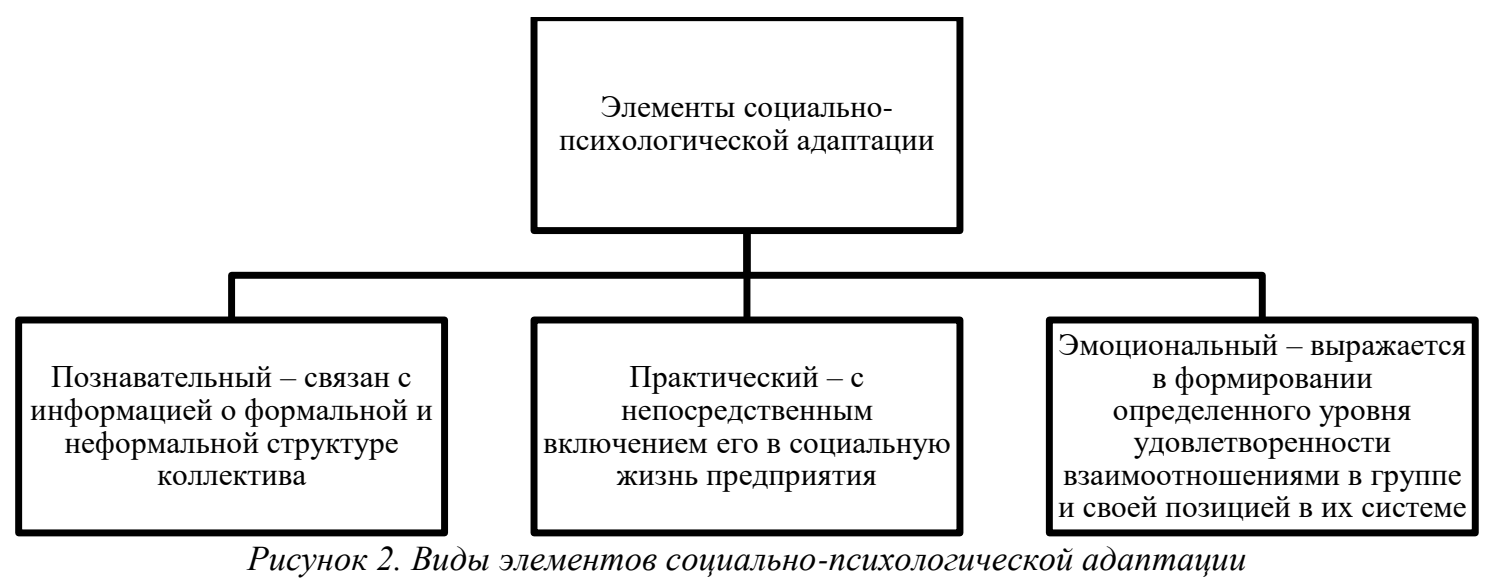

В процессе социально-психологической адаптации происходит включение работника в систему взаимоотношений коллектива с его традициями, нормами жизни, ценностными ориентациями. В ходе такой адаптации сотрудник получает информацию о системе деловых и личных взаимоотношений в коллективе и отдельных формальных и неформальных группах, о социальных позициях отдельных членов группы. Эту информацию он воспринимает активно, соотнося ее со своим прошлым социальным опытом, со своими ценностными ориентациями. При принятии сотрудником групповых норм происходит процесс идентификации личности либо с коллективом в целом, либо с какой-либо формальной или неформальной группой [5, с. 114]. 
Характеристика функций социально-психологической адаптации представлена на рисунке 3.

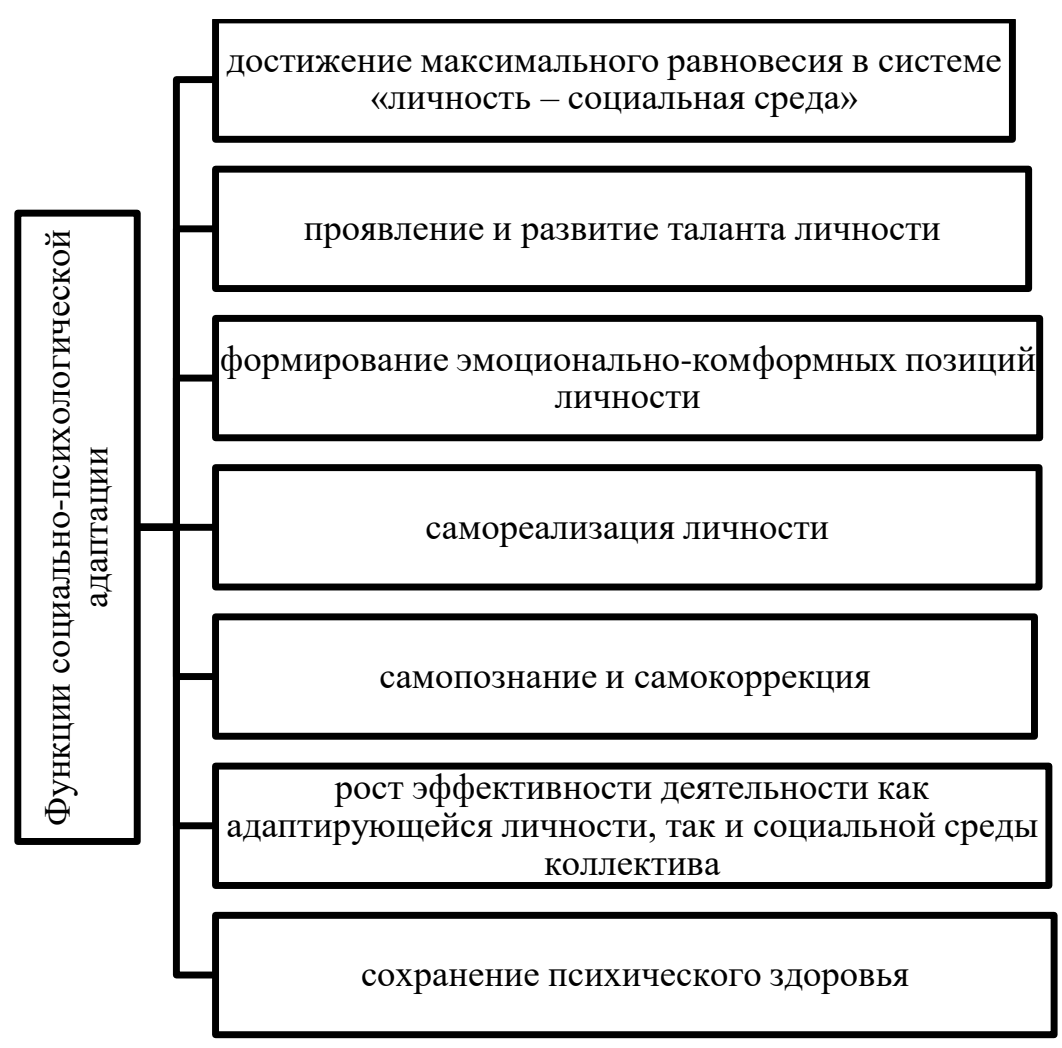

Рисунок 3. Функиии соџฺиально-психологической адаптаџฺии

Социально-психологическая адаптация - это адаптация к коллективу и его нормам, к руководству и коллегам, к экономическим реалиям $[6,7,8]$. Она может быть связана с немалыми трудностями, к которым относятся обманутые ожидания быстрого успеха, обусловленные недооценкой трудностей, важности живого человеческого опыта и переоценкой значения теоретических знаний и инструкций $[9,10]$. Социальнопсихологическая адаптация может быть осложнена в связи с обманутыми ожиданиями быстрого успеха, с недооценкой проблем, трудностей в общении. На социальнопсихологическую адаптацию более мощное воздействие оказывает индивидуальность личности, следовательно, сугубо личные привычки и умения строить свое поведение.

$$
* * *
$$

1. Балл Г. А. Понятие адаптации и его значение для психологии личности //Вопросы психологии. - 1989 - №1. - С. $92-100$.

2. Беляцкий Н.П. Управление персоналом: Учеб. пособие / Н.П. Беляцкий, С.Е. Велесько, П. Ройш. - 3-е изд., стереотип. - Мн.: Книжный Дом; Экоперспектива, 2015. - 352 с.

3. Жмыриков А.Н. Диагностика социально-психологической адаптированности личности в новых условиях деятельности и общения. Л., 1989. 227c.

4. Адлер А. Практика и теория индивидуальной психологии. М., 1995. 189c.

5. Беляцкий Н.П., Велесько С.Е., Ройш П.Г. Управление персоналом. Минск: Экоперспектива, 2015. 344 с.

6. Андреева Г.М. Социальная психология. - М.: Аспект Пресс, 2001. - 376с.

7. Володина, Н.В. Адаптация персонала / Н.В. Володина. - М. : Эксмо, 2009. - 240 с.

8. Климов Е. А. Психология профессионала. - М.: ИПП, 1996. - 400 с.

9. Коханов Е. Ф. Отбор персонала и введение в должность. М., 1996.

10. Мельникова Н.Н. Классификация стратегий адаптивного поведения//Теоретическая, экспериментальная и практическая психология: Сборник научных трудов / Под ред. Н. А. Батурина. - Челябинск: ЮУрГУ, 2001 T.3. - C. $13-23$. 